\title{
Understanding the Perception of Lifelong Learning Programmes Requirements towards Employee's Career Development
}

\author{
Zarina Kassim, Nor Aishah Buang, Norhidayah Mohamad
}

\begin{abstract}
The implementation of the Lifelong Learning programmes (LLL) is aimed to raise the level of knowledge and skills of employees thus developing human capital through increased productivity and competency. However, the extent to which Small and Medium Enterprises (SME) employees feel that this LLL programmes as a requirement for them in career development is still in question. This study aims to explore the perceptions of SME employees on LLL programmes requirements in their career development. This study applied a qualitative approach using case study design. A total of 11 SME employees were selected as its participants. The findings show that the average participants of this study agreed that there is no need for them to engage in the LLL programmes in terms of promotion from employers. This is because SME employers are more committed to working experience, working commitments and social skills. However, in the opinion of SME employees there is a need for them to join the LLL programmes for the purpose of salary increment from employers and opening up other better employment opportunities in their career development.
\end{abstract}

Index Terms: Lifelong Learning (LLL), Career Development, Small and Medium Enterprises (SME's), Education Needs

\section{INTRODUCTION}

Small and Medium Enterprises (SMEs) are the major contributors to the highest rate of employment in the country (Table 1). The increase in employment rate each year shows that SMEs have opened up various jobs and business opportunities. This proves that SMEs are an important sector of economic and socio-economic aspects that need to be taken into account accordingly. Recognizing this fact, human resource development strategies need a neat and dynamic planning according to the change of time as well as holistic planning in terms economic and social aspects. In 2002, the k-Economy Development Blueprint was launched and for the first time the government provided emphasis on lifelong learning needs for the workers. Then, in 2011, the Ministry of Higher Education (KPT) launched a Lifelong Learning (LLL) programmes through the Lifelong Learning Cultivation Master Plan (2011 -2020) in more details. In line with the country's economic development aspirations based on quality working capital, the LLL programmes is designed

Revised Manuscript Received on September 22, 2019.

Zarina Kassim, Faculty of Education, Universiti Kebangsaan Malaysia,

Nor Aishah Buang, Faculty of Education, Universiti Kebangsaan Malaysia

Norhidayah Mohamad, Faculty of Social Science and Humanities, Universiti Kebangsaan Malaysia, Malaysia to produce a competent workforce that will create a knowledgeable society and generation. It is also in line with the government's goal to strengthen the education delivery and training system, especially to low educated and skilled workers. Hence, the programmes are seen as an opportunity that every SME employee needs to grab to improve the level of professional education, learn new skills, thereby enhancing the level of working efficiency. This is because, the issue of unskilled workers and low productivity is synonymous with SME employees because they are less exposed to education programs and training from employers [1]. The proof, only $21 \%$ (2.05 million) of SME employees are involved in education and training programs under Human Resource Development Berhad (PSMB) [2].

\begin{tabular}{|c|c|c|c|c|c|}
\hline Year & 2013 & 2014 & 2015 & 2016 & 2017 \\
\hline KDNK & 36.3 & 35.9 & 36.3 & 36.6 & 37.1 \\
\hline
\end{tabular}

However, the question arises whether there is a need for SME employees to participate in the programmes in terms of career development? This is because SME jobs are not characterized by professional work. In fact, the type of SME job also does not require high levels of education and skills. Professional work requires the intellectual ability, having autonomy in the assignment, the job is a unique and important workforce service and that the employee needs a special training [3]. Hall [4] states that the career definition is focused only on professional and hierarchical organizations. However, Jackson, Arnold, Nicolson and Watts [5] emphasized that career development refers to the summarization of psychological, sociological, knowledge, physical, economic and the desire to transform the individual's career direction for the well-being of his life. This is because career development is a process for achieving organizational as well as career goals for employees. This means that the type of job that has the characteristic of low educated and skilled workers also has a level of career development although they are not among professional workers [6].

Hence, this study aims to explore the perception of SME employees on the need to participate in the LLL programmes in terms of career development. The findings of this study led to new findings

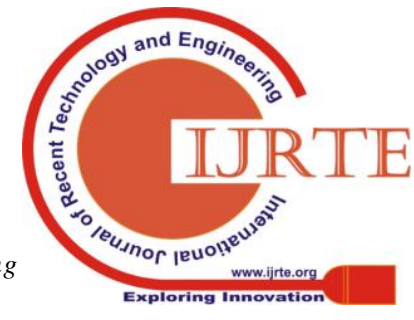


among SME's low educated and skilled workers. The interview results found that the average of the study participants agree that there is no need to participate in the SME program if the main goal of the employee is to get job promotions. This is because; SME employers do not prioritize education levels for the improvement of their employees' careers. Instead, SME employers prioritize working experience, committed employees and employees that have good social skills. However, the participation of SME employees in the LLL programmes may lead to salary increments from employers but only at the discretion of the employer itself. Besides that, participation in the LLL programmes will help SME employees to get better job opportunities. This study leads to some implications. The first implication, emphasis should be given to the development and investment in infrastructure, continuous improvement programs and improvements of the courses offered at Higher Learning Institutes and LLL programmes providers. Based on the findings from the literature, there are still many weaknesses that need to be enhanced through the quality of program implementation, especially at tertiary level and LLL program providers. Furthermore, this also leads to the second implication, in which, the government and LLL programmes providers should promote the LLL programmes more proactively and effectively as the average interview participants do not know more in detail about the LLL programmes. This is supported by the results of the study from Jamunarani [7] which found the level of community knowledge of the LLL programmes is at low moderate levels. Thirdly, the government needs to open up business opportunities to SME employees such as INSKEN's educational and entrepreneurial skills programs tailored to students at Higher Learning Institutions. The implication of this study is based on the findings which shows that the average participants intended to open their own business.

\section{LITERATURE REVIEW}

\section{A. SME Employee's Barriers in HRDF Programmes}

Human Resource Development Berhad (HRDF) which was established in 1992 is responsible for managing education and training to SME employers and employees in the country. However, not all SME employers are required to register. Only medium and small sized SME employers are required to register while micro SMEs are excluded. Post-research studies have been conducted by previous researchers to identify the status and determination of SME employee's involvement in education and training through the HRDF program. According to Hande Karadag [8], employers play an important role in the involvement of SME employees in education and training. In fact, Hande Karadag's statement (2017) was true based on the evidence of studies that showed SME employers in the country tend to choose employees for education and training based on the level of education, work experience, the ability of employees to perform important tasks and job categories [9] [10]. Employers also prefer skilled workers to education and training because they will have higher output returns than unskilled workers [11].

However, in 2016 reports from the Malaysian Productivity Corporation (MPC) [12] in collaboration with HRDF and the Ministry of Human Resources found that SME employers had limited capacity to provide education and training opportunities to employees under the HRDF scheme. The survey of 740 SME employers found that SME employers were unable to send their employees under the HRDF scheme due to the small number of employees (no program for small group of employees), strict work schedule (not suitable for short training program), employers did not know which type of training that is suitable to the needs of its employees, the issue of cash flow and the expenses of the employer, no available training center in the area, the employer does not have a specialized human resource unit to handle the training of the employees, no training program appropriate to employer's requirements, and employers collect levy money for more important training (there is no cheaper training). However, in 2016 reports from the Malaysian Productivity Corporation (MPC) study in collaboration with HRDF and the Ministry of Human Resources found that SME employers had limited capacities to provide education and training opportunities to employees under the HRDF scheme.

Based on the studies conducted by Latifah and Ramli [13], as well as Arifin [14], the findings have shown positive feedback from SME employers as a whole on aspects of program evaluation, modules, tutors, quality and basic skills, special skills, knowledge and understanding. In this regard, the LLL programmes is seen as the best opportunity for SME employers to increase the level of knowledge, skills and competencies of their employees as the more open-ended learning methods, affordable fees and flexible usage of learning time than HRDF programs.

\section{B. LLL Programmes as Evolution in the Education System}

The progress in technology and communication has had an impact on evolution in today's educational system. Teaching and learning activities are no longer taking place in lecture rooms alone but can happen anywhere and at any time. The LLL programmes is one of the learning models that adopt flexible learning methods in support of the involvement of the workforce in education and training in the country. Effective program implementation strategies at the ministry and program providers are constantly strengthened from time to time. Among them are funding assistance to the community, enhancing the effectiveness of learning methods, especially Open Distance Learning (ODL) and accreditation policy adjustments so as not to cause confusion between industry and society [15]. In fact, Higher Education Institutions have always played a role in improving the quality of education. Among the efforts to attract the workforce involved in the LLL programmes are the sustainability and enhancement of institutional quality from various aspects such as the quality of the program in terms of curriculum design according to the needs of human resource development, delivery methodology, extending the study, improving the quality of the management system, and strengthening collaboration 
between institutions and industries to achieve satisfaction among workers and employers [16].

Other studies by [17] - [27] have also been carried out to improve quality assurance in delivering LLL programmes to be in line with LLL programmes goals. There are also previous studies that examine the effectiveness of the LLL program as a result of the evolution of the education and training system in the country.

The study of the effectiveness of the LLL programmes by Mariambe and Ahmad Shaharil [28] found that the LLL programmes for short-term courses had a positive impact on the increase in participants' income. The findings of the same study on the community were carried out by Yufiza, Siti Saleha and Noorhidayah [29] while the study of effectiveness on entrepreneurs was carried out by Norsela and Nur Ilyana [30] The study of Sharifah Masitah, Fadzillah and Nordin [31] on the Tahfiz groups found that there was awareness about the importance of the LLL programmes through increased knowledge and skills for self-development of participants.

Hence, in view of the findings from previous studies, researchers view that the LLL programmes opens up space and opportunities for SME employees to increase their capability and potential in career development without relying on initiatives from employers. This is in line with the views of Marhaini and Nur Liza [32] which state that there are three processes in career development planning ie, i) individuals need to identify opportunities and realize the impact of each action, ii) the individual will identify the goals to be achieved, and iii) the individual will plan steps to achieve goals such as engaging in education and training. Hence, SME employees can plan their own career to be developed and supported by employers [33]. Effective career development planning unites between the needs, capabilities, needs and desires of individuals with human resource planning as a whole.

\section{METHODOLOGY}

\section{A. Research Method}

This study is aimed at exploring the perception of SME employees on the need to engage in the LLL programmes from a career development perspective. This study uses a case study design as researchers are able to understand the phenomenon of the need for education and training programs in terms of career development based on the views of SME employees. This case study addresses the "how" and "why" questions [34]. In particular, how do SME's perceptions of the need to engage in LLL programmess from a career development perspective and understand how the LLL programmes helps in the development of their careers. In addition, why workers feel there is a need or there is no need to join the LLL programmes. This study is to identify program needs based on the actual experience of career paths in SMEs. Semi-structured interviews were used as researchers had information on issues studied based on literature review [35]. This method allows researchers to interact with subjects [36]. Before conducting this interview, researchers have made early planning to manage interview sessions using logical approaches. Figure 1 shows a study framework consisting of 6 major steps in sequence except for the fifth and sixth steps repeated for each interviewer.

The sample was selected with the aim of selecting the participants in a typical manner, which is to determine the specifics of typical respondents. Merriam [37] suggested that the researcher first identify the main criteria of the study participants and the location of the study. Therefore, the main features of interviewing participants are; i) SME employees who work full time and the work done is the main revenue earner, ii) have a two year service record with their current employer. They have experienced the experience of working in the SME sector by understanding the characteristics of their employers and their work policies well. Hence, they are expected to provide knowledge and provide the necessary information. Participants in the study have both graduate and non-graduate backgrounds to see the difference in their perception of career development [38].

\section{B. Data Analysing}

In qualitative research, the data collection and analysis process is done simultaneously to prevent researchers from dropping out important information due to data dumping. Each time the researcher finished interviewing the participants, all entries from the interview were recorded in the form of an interview transcript and recorded as raw material. Researchers used the help of computer software Atlas.ti to store, organize and analyze data. Inductive encoding is done first by open encoding before the axial coding and selective coding [39]. Interviews are terminated once the data is saturated, that is when no new themes arise. The researcher examines the causes and consequences, the circumstances and interactions, strategies and processes contained in the overall data. The relevant themes are grouped together. Next, the researcher displays the themes and categories to get an overview of the interactions between themes.

\section{RESULTS AND DISCUSSIONS}

The interview protocol used by researchers in this study consists of nine questions. Table 2 (See Appendix) shows questions and summaries of themes from interviews. The first question is the opening question to build relationships with participants. Findings show that almost all participants did not have higher education. Four (4) participants had diploma education while six (6) more had SPM certificates (5) and STPM (1). While another participant has a certificate of skills from Baitulmal, Selangor. The second question relates to the need to participate in the LLL programmes based on the employer's policy. Most participants stated that employers did not place any policies if employees wanted to engage in education and training. However, employers do not provide any forms of incentive to employees. Based on this question, the study participants successfully answered why the employer did not provide any kind of support for learning. The third question, regarding the participants' mindset of planning in career development. The results show that all participants have plans and initiatives to improve the level of career development in the future based on their level

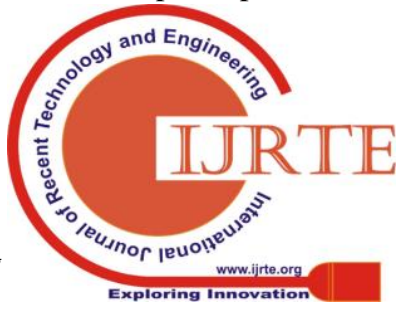


of capabilities and desires. The fourth question is to identify the participants of the study on the need to participate in the LLL programmes. All participants stated that the LLL programmes were not important if the participant's goal was to solely benefit the employer's prospects because the employer did not care about the level of education for promotion. In fact, most participants say there is no chances of promotion within the organization due to the size of the small employer's business. However, the participants stated there was a need to participate in the LLL programmes for salary increment but at the discretion of the employer, as well as opening up opportunities for more secure future employment.

The fifth question is to understand the views of SME employees on the willingness to engage in the LLL programmes even though they have no support from employers. Researchers found that even though average SME employees had a positive outlook on the need to participate in the LLL programmes in terms of career enhancement, five (5) participants were not ready to participate in the LLL programmes in the near future as there were more important commitments and financial problems. While four (4) more participants do not have problems attending the LLL programmes at any time. The sixth question relates to the level of SME employer support towards employee involvement in the LLL programmes in terms of recognition. The average participants stated that there was no form of recognition from employers if they were involved in the LLL programmes. However, three (3) of the participants told them they can apply for salary increase from employers but depending on the employer's discretion. There is a participant expressing through the increase in professional education, he has the opportunity to apply for a higher salary and salary than an employer if there is a vacancy. While the other participants (7) state that there is no form of recognition from employers.

The seventh question is to explore the views of SME employees to answer the question "why" they still want to participate in the LLL programmes although there is no form of encouragement from employers in terms of promotion or salary. The findings show that the average study participants have their own career planning. Five (5) of the study participants intend to open their own business because the experience of working with SME employers has attracted them to become entrepreneurs. One of the participants stated he was interested in generating side income through small business. While two (2) participants intend to get employment opportunities in other areas. Therefore, researchers suggest that entrepreneurship programs in LLL programmes are implemented more effectively to help participants understand the intricacies of business management as well as ways to build their business. The eighth question relates to the relevance of the current employment as SME employees with their career plans in the future. The average study participants gave their views that their current job in SMEs was to gain experience in entrepreneurship and business management. While the ninth question aims to understand the obstacles faced by SME employees to engage in the LLL programmes. On this question, nine (9) participants expressed the problem in terms of educational funding, but suggested other alternative solutions to this obstacle by applying loans from PTPTN, MARA; seeking help from Baitulmal, state Zakat funds and etc. In addition, two (2) out of the participants stated that the age factor had increased, four (4) felt that they were not eligible to enter any college because of the unfavorable SPM results.

From a constant comparison between one case and the next it was found that there is a pattern of similarity in interviewing answers even in the context of different backgrounds. From the level of education and experience in the career of these SME employees, it shows that they are influenced by the urge to engage in business as entrepreneurs. They have the basic skills and knowledge in the field of business that are acquired from experience throughout the SME field. They also have similar entrepreneurial attitudes, willingness to engage in education and training and motivational strength. Therefore, they have an awareness of the need for involvement in the LLL programmes in career development based on their plans. From this interview, researchers found that participants have the interest to improve their knowledge and skills, have experience and skills in managing their business. However, the ability to identify opportunities in education and training participation needs to be enhanced through a more proactive and innovative attitude in identifying opportunities in the environment. All of these elements can be categorized according to certain themes and subthemes summarized in Table 3 .

TABLE III: THEME, Sub THEME AND SuB THEME

\begin{tabular}{|c|c|c|}
\hline Theme & Sub Theme & Sub Sub Theme \\
\hline $\begin{array}{l}\text { Top } \\
\text { Rank }\end{array}$ & $\begin{array}{l}\text { Promotion } \\
\text { opportunity }\end{array}$ & $\begin{array}{l}\text { There is the support of employers } \\
\text { in terms of promotion. } \\
\text { No employer support. }\end{array}$ \\
\hline Salary & $\begin{array}{l}\text { Salary } \\
\text { Opportunity }\end{array}$ & $\begin{array}{l}\text { There is incentive salary increase } \\
\text { from employer. } \\
\text { No incentive. }\end{array}$ \\
\hline \multirow{3}{*}{$\begin{array}{l}\text { Other } \\
\text { career } \\
\text { Side } \\
\text { income }\end{array}$} & Career & $\begin{array}{l}\text { Exploring other career } \\
\text { opportunities. }\end{array}$ \\
\hline & $\begin{array}{l}\text { Generating } \\
\text { other income }\end{array}$ & Opens other income generating \\
\hline & & Opportunities through side work. \\
\hline
\end{tabular}

\section{CONCLUSION}

This paper discusses a qualitative study using case study method. As a result of interviews, SME employees are of the view that SME employers actually have a positive perception of programmes requirements to their employees but, on average, employers cannot provide support in terms of career development. This is because SME is a small business. Hence, there are various constraints to employers in terms of appreciation and respect for employees involved in the LLL programmes. Besides that, SME's small business orientation also makes it unnecessary for employees to have approval and o be highly skilled. In addition, SME employees have also successfully linked the LLL programmes requirements to career development in terms of promotional opportunities, salary increases and other career opportunities. This finding illustrates the positive understanding and perception of SME employees on the need for continuous learning programmes. Hence, this study confirms that the LLL programmes has been a guide to research participants to enhance the level of knowledge and skills, alter the individual's

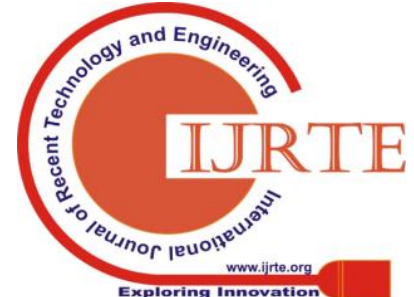


attitudes, promote career development and enhance the individual's ability in education and training.

\section{ACKNOWLEDGMENT}

This research work is supported by the Project (Research Project GC-2014-11)

\section{REFERENCES}

[1] Norsyafiqah., A., B.,\& Azizan., M.(2017). Industri Kecil dan Sederhana di Malaysia. 2017. DOI:10.13140/RG.2.2.25726.38724

[2] SME Developments and Outlook: The Third Quarter 2017 (3Q 2017) SME Survey. SME Annual Report 2017/2018.

[3] Skinner \& Suzi. (2019). How can Developmental theories help clarify career transitions for Clients?

[4] Hall, D.,T. (1976). Careers in Organizations. Pacific Palisades, CA: Goodyear.

[5] Jackson, C., Arnold, J., Nicholson, N., \& Watts, A,G. (1996). Managing Careers in 2000 and Beyond. Brighton: The Institute for Employment Studies.

[6] Watts, A.G. (1981). Career Patterns. In A.G Watts., D.E Super, \& J.M Kidd (Eds), Career Development in Britain: Some Contributions to Theory and Practice, (pp. 213-245). Cambridge: CRAC/Hobsons.

[7] Jamunarani., M. (2014). Penglibatan Komuniti dalam Kursus Pendek Anjuran Jabatan Pembelajaran Sepanjang Hayat Kolej Komuniti Kuala Langat. Presented at the Seminar Kebangsaan Pembelajaran Sepanjang, Hayat, Open University Kuala Lumpur, Malaysia.

[8] Hande Karadag. (2017). The Role of SME's and Entrepreneurship on Economic Growth in Emerging Economies within the Post-Crisis Era. An Analysis from Turkey. Business and Management Studies. Vol 1, No.2; September $2015.2374-5916$ https://www.researchgate.net/publication/314074436

[9] Rahmah, I., Zulridah M.N., \& Salma, H. (2013). Penentu Penglibatan Pekerja Dalam Latihan Pembangunan Sumber Manusia Berhad. Jurnal Ekonomi Malaysia 47(1) 2013109 - 124.

[10] Sa'adiatul.,M. (2016) Persepsi Pekerja Terhadap Pembangunan Kemahiran Sumber Manusia Di Kulim Hi-Tech Park. Masters thesis, Universiti Sains Malaysia.

[11] Rahmah, I., Zulridah, M.N., \& Awang, A.H. (2011). Impact of Training Under Human Resource Development Limited On Workers' Mobility In Selected Malaysian Services Sector. Eurasian Business Review Volume 2 (2011) $146-159$.

[12] Malaysia Productivity Corporation 2016/2017. (2017). ISSN: 1394-410X

[13] Latifah., A., L \& Ramli ., B. (2014). Employability Skills: Closing the Gap between Employers' Expectations and Satisfaction. Presented at the Seminar Kebangsaan Pembelajaran Sepanjang Hayat, Open University Malaysia, Kuala Lumpur, Malaysia.

[14] Arifin, H., Z. (2014). Maklum Balas Pelajar Terhadap Program Prasiswazah Fakulti Sains Sosial Gunaan (FASS). Presented at the Seminar Kebangsaan Pembelajaran Sepanjang Hayat, Open University Malaysia, Kuala Lumpur, Malaysia.

[15] Mansor., F. (2014). Encouraging Lifelong Learning: The Malaysian Context. Presented at the Seminar Kebangsaan Pembelajaran Sepanjang Hayat, Open University Malaysia, Kuala Lumpur, Malaysia.

[16] Thirumeni, S., \& Latif, L.A. (2014). Lifelong Learning and Quality Workforce: A Way Forward in Research and Innovation For OUM. Presented at the Seminar Kebangsaan Pembelajaran Sepanjang Hayat, Open University Malaysia, Kuala Lumpur, Malaysia.

[17] Goolamally, N., \& Latif, L. A. (2014, December). Determinants of Student Loyalty in an Open Distance Learning Institution. Presented at the Seminar Kebangsaan Pembelajaran Sepanjang Hayat, Open University Malaysia, Kuala Lumpur, Malaysia.

[18] Nur, H. M., Agos, A. M., \& Jaruma, S. B. (2014). Kajian Keperluan Kursus Pendek Kolej Komuniti Dalam Kalangan OKU: Satu Kajian Kes di Kolej Komuniti Tanjung Piai. Presented at the Seminar Kebangsaan Pembelajaran Sepanjang Hayat, Open University Malaysia, Kuala Lumpur, Malaysia.

[19] Kassim., M., A., Yusof.,Z.,M., Rahmat.,M.,F., Kassim., \& S., Ahmad., N.,A. (2016). Cabaran Perlaksanaan Program Pembelajaran Sepanjang Hayat (PSH) di Pusat Pembangunan Profesional (PPP),UTMSpace. Presented at the Seminar Kebangsaan Pembelajaran Sepanjang Hayat, Open University Malaysia, Kuala Lumpur, Malaysia.

[20] Nabil Fikri A., H., \& Roswani A., R. (2014). Pembangunan Modal Insan Menerusi Pendidikan Sepanjang Hayat di Kolej Komuniti. Presented at the Seminar Kebangsaan Pembelajaran Sepanjang Hayat, Open University Malaysia, Kuala Lumpur, Malaysia.

[21] A.,Halim., M., N., Hamzah., M.,I., \& Haron., Z. (2016). Pendekatan Fleksibel dalam Pengajaran dan Pembelajaran bagi Menggalakkan
Pendidikan Sepanjang Hayat di Malaysia. Presented at the Seminar Kebangsaan Pembelajaran Sepanjang Hayat, Open University Malaysia, Kuala Lumpur, Malaysia.

[22] Afendi, H., Mohamed Amin, E., \& Sulaiman, A. H. (2011). Learning Management Systems in Malaysian Higher Education Institutions. In M. A. Embi (Ed.), "Learning Management Systems Among Malaysian University Lecturers". The International Journal of Learning: Annual Review 18(4): 61-70

[23] Zahiah, K., \& Ahmad, A, R. (2011). E-Pembelajaran: Evolusi Internet Dalam Pembelajaran Sepanjang Hayat. Proceedings of Regional Conference on Knowledge Integration in ICT 2010, 209-218.

[24] Seth, A \& T. Goolamally., N. (2014). Pilot Study to Develop a Problem Based Learning Environment for Open Distance Learners. Presented at the Seminar Kebangsaan Pembelajaran Sepanjang Hayat, Open University Malaysia, Kuala Lumpur, Malaysia.

[25] Abby, A.S., Goolamally, N., Latifah A, L. (2014). Embedding or Codes in the Teaching and Learning Process. Presented at the Seminar Kebangsaan Pembelajaran Sepanjang Hayat, Open University Malaysia, Kuala Lumpur, Malaysia.

[26] Harvinder Kaur, D.S., Yusof, S., \& Lim, T.M. (2014). Self-Managed Learning Of Myvle Via Cbt Courseware. Presented at the Seminar Kebangsaan Pembelajaran Sepanjang Hayat, Open University Malaysia, Kuala Lumpur, Malaysia

[27] Ahmad., I.,A., Nik Azlina., N., Y.,\& Kamariah M.,N. (2014). A Comparative Study on Persistency and Performance Of Flexible And Normal Entry Learners. Presented at the Seminar Kebangsaan Pembelajaran Sepanjang Hayat, Open University Malaysia, Kuala Lumpur, Malaysia

[28] Mariambe Mustaffa, Ahmad Shaharil Jamaludin. (2014). Kajian Keberkesanan Kursus Pendek Membaiki Telefon Bimbit Di Kole Komuniti Bayan Baru, Pulau Pinang. Presented at the Seminar Kebangsaan Pembelajaran Sepanjang Hayat, Open University Malaysia, Kuala Lumpur, Malaysia

[29] Yufiza.,M.,Y, Siti Saleha., A.,A., \& Noorhidayah., M. (2014) Pembelajaran Sepanjang Hayat Pencetus Kemahiran secara Holistik dalam Membangunkan Komuniti. Presented at the Seminar Kebangsaan Pembelajaran Sepanjang Hayat, Open University Malaysia, Kuala Lumpur, Malaysia.

[30] Norsela A.,M \& Nurul Ilyana.,B. (2014). Keberkesanan Latihan Terhadap Usahawan Industri Kecil dan Sederhana (IKS) Sabak Bernam. Presented at the Seminar Kebangsaan Pembelajaran Sepanjang Hayat, Open University Malaysia, Kuala Lumpur, Malaysia.

[31] Sharifah., M., S., M., Fadzillah., M., Y., \& Nordin., S. (2014). Tinjauan Kursus Pendek Kolej Komuniti Pasir Gudang terhadap Golongan Tahfiz di Kawasan Pasir Gudang. Presented at the Seminar Kebangsaan Pembelajaran Sepanjang Hayat, Open University Malaysia, Kuala Lumpur, Malaysia.

[32] Marhain., A., G, Ramli., N., L.,. (2017). Faktor-faktor yang Mempengaruhi Pembangunan Kerjaya di AlHijra Media Corporation (TV Al-Hijrah). Proceeding of the 4th International Conferece of Management and Muamalah 2017.

[33] Bakri., N, Kiong., Y.,S, \& Hussin.,H. (2009). Hubungan antara Peranan Individu dan Organisasi dengan Amalan Pembangunan Kerjaya. Journal of Human Capital Development.

[34] Yin, R. K. (1994). Case study research: design and method. Thousand Oak, California: Sage Publications, Inc.

[35] Cavana, R. Y., Delahaye, B. L. \& Sekaran, U. (2001). Applied business research: Qualitative and quantitative methods. Milton, Queensland: John Wiley \& Sons Australia, Ltd.

[36] Wiersma, W. (2005). Research methods in education: An introduction Edisi ke-6. Massachusetts: Allyn and Bacon.

[37] Merriam, S.B. 2009. Qualitative Research. San Francisco: Jossey-Bass.

[38] Cresswell, J. W. \& Clark, V. L. P. (2007). Designing and conducting mixed methods research. Thousand Oaks: Sage Publications, Inc.

[39] Strauss, A. \& Corbin, J. (1998). Basics of qualitative research: Tecniques and procedures for developing grounded theory Thousand Oak Sage Publications. 


\section{AUTHORS PROFILE}

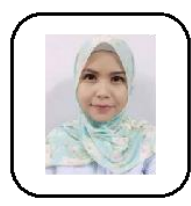

Dr Zarina Kassim has completed Doctor of Philosophy at Universiti Kebangsaan Malaysia. Dr Zarina's broad academic interests involve Economics Education, Entrepreneurship, Adult \& Continuing Education, Small and Medium Enterprises (SME's) and Economics Development. She is currently a researcher at Faculty of Economics \& Administration, University of Malaya, Malaysia. She has published several academic articles in national and international refereed journals.

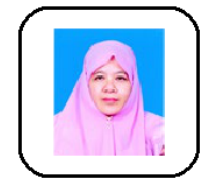

Prof. Dr Nor Aishah Buang is a professor at the Department of Leadership Professionalization, Faculty of Education, Universiti Kebangasaan Malaysia. She received her Bachelor Degree from Fresno California, USA; then completed Master of Education (Secondary Education-Economics Education) in the University of Minnesota, USA. She was awarded Ph.D (Curriculum and Instruction) from the Indiana University, Bloomington,
USA. She also did her Post Graduate Diploma in Entrepreneurship in Cambridge University, UK. Her research is mainly in entrepreneurship education. She is currently a member of Ahli Malaysia Educational Research Association, the chair of the Asean Comparative Education Research Network and the secretary of the Asean Comparative Education Research Network. She has published a number of articles in Scopus indexed journals.

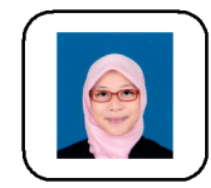

Norhidayah Mohamad is an ambitious person that interested in professional development and researching, ongoing learning and growth, who likes to communicate and working with new ideas and people. She currently pursues her Master of Philosophy (M.Phil) in Development Science at Universiti Kebangsaan Malaysia (UKM). She earned a Bachelor of Administrative Science (Honours) in 2016 from Universiti Teknologi Mara (UiTM). Her main research interests are in the areas of resilience community, urban community and community development.

\section{APPENDIX}

Table II: Interview Summary

\begin{tabular}{cll}
\hline No. & Question & Theme Summary \\
\hline 1 & Can you explain briefly about your own background in The impact of age background, education level and \\
terms of age, level of education and how many years of experience of working with employers. \\
your employer is employing now?
\end{tabular}

2 Can you tell me about the need to participate in education The level of employer support for the need to engage in and training programs such as the LLL program in terms education and training programs such as the LLL of career development with the current employer? Does programmes. your employer have a policy to comply with any such program?

3 How do you want to improve your career development? Are Understanding level of thinking of SME employees on you comfortable with the current level of your career? initiatives in career development.

4 Is your involvement in education and training programs such SME employee perceptions of the need to participate in the as the LLL program important for your future career LLL programes. development?

5 Will you join an LLL program for future career The level of thinking and the willingness of SME employees development if your employer does not provide any form of to be involved in the LLL programmes.

help or encouragement?

6 Does your employer provide any kind of privilege to an Recognition of employers in career development as an employee who is successful in improving the level of impetus to join the LLL programmes.

professional education or enhancing skills through recognized courses?

7 If an employer cannot provide learning encouragement in There is a need to join the LLL programmes in terms of terms of career development as there are no promotion career development at a new job or self employed by opportunities and so on, why do you still feel that there is a becoming an entrepreneur. need to join the LLL programmes?

8 What is your view of current employment with your plans Current work to gain experience in entrepreneurship and for career development in the future? business management but aims to increase knowledge and skills through learning is for the benefit of future careers.

9 What are the obstacles that make it difficult for you to Commitment in life such as family responsibilities cannot engage in education and training programs such as the cease working solely for continued learning due to financial LLL programmes? factors and unsupportive employers regarding their involvement in the LLL programmes. 